\title{
O pensamento de Jacques Maritain e de Emmanuel Mounier no campo católico brasileiro e a educação libertadora de Paulo Freire
}

\author{
The Ideas of Jacques Maritain and \\ Emmanuel Mounier on the Brazilian Catholic \\ Field and the Liberation Education of Paulo Freire
}

Rogério Luiz de Souza ${ }^{*}, *$

\section{Resumo}

$\mathrm{O}$ artigo examina a força interventora de uma militância católica brasileira após a Segunda Guerra Mundial, impulsionada por uma matriz intelectual francesa e pelas experiências de vivência nos espaços de vulnerabilidade social. Paulo Freire, alvo específico da análise deste artigo, foi um desses militantes católicos dedicado ao campo educacional. Em sua obra Educação como prática de liberdade, publicada em 1967, Freire aplicou e formulou uma pedagogia da ação inspirada na filosofia política de Jacques Maritain e na filosofia da ação de Emmanuel Mounier, estabelecendo uma relação com a teoria marxista. Para melhor compreender essa movimentação dos atores sociais católicos e, em particular, de Paulo Freire na elaboração de um novo discurso pe-

\begin{abstract}
The article examines the interventional force of the Brazilian Catholic militancy after the Second World War, which enabled for a French intellectual matrix and through the living experiences in spaces of social vulnerability. The specific target of the analysis of this article focuses on how Paulo Freire was one of these dedicated militant Catholics in the field of education. In his work Educação como prática de liberdade [Education as Practice of Freedom], published in 1967, Freire applied and created a pedagogy of action inspired by the political philosophy of Jacques Maritain and the philosophy of action of Emmanuel Mounier, establishing a relationship with Marxist theory. To better understand this movement of social Catholic actors and in particular, of Paulo Freire on the elabo-
\end{abstract}

\footnotetext{
* Universidade Federal de Santa Catarina (UFSC), Departamento e Programa de Pós-Graduação em História, Florianópolis, SC, Brasil.

** Universidade Aberta de Lisboa (UAb), Programa de Doutorado em Estudos Globais, Lisboa, Portugal. rogerklaumann@gmail.com <https://orcid.org/0000-0002-0097-7466>
} 
dagógico e de uma nova ação político-social no Brasil, o artigo mobiliza os conceitos de campo social em Pierre Bourdieu e de genealogia das relações de poder em Michel Foucault.

Palavras-chave: catolicismo social; pensamento católico francês; militância católica; Paulo Freire; educação libertadora. ration of a new pedagogical discourse and a new political social action in Brazil, this study presents the mobilization of the concepts of the social field of Pierre Bourdieu and Michel Foucault's genealogy of power relations.

Keywords: social Catholicism; French Catholic thinking; Catholic militancy; Paulo Freire; liberation education.

Muitos pensadores e militantes católicos brasileiros, após os abalos da Segunda Guerra Mundial, procuraram estar atentos ao pensamento católico francês e associar as suas estratégias de transformação social nos campos escolar, político, econômico, sindical e teológico e em outros espaços e campos de poder. Muitos foram até mesmo ao continente europeu e se enfronharam em experiências de trabalho, estudo, cooperação e vivências sociais. Foram pensadores, estudantes de teologia, políticos, sindicalistas, padres, professores e operários que, ao desembarcarem em França, Bélgica, Itália e Alemanha, consumiram, ressignificaram e possibilitaram a circulação de um pensamento e de uma prática social que serviu para constituir um novo paradigma de ação político-social no Brasil a partir dos processos de mudança político-econômica que ocorreram a partir de 1945.

Nesse sentido, a teoria de campo social proposta por Pierre Bourdieu diz bem para o que se quer discutir aqui. Os pensadores e militantes que pertenciam, especificamente, ao campo católico do período ou nele se inseriram buscaram fazer valer suas posições e obter espaço, reconhecimento e prestígio dentro do seu próprio campo de atuação e em outros campos de poder e de saber em disputa. Afinal, todo campo é um campo de forças em disputa para conservar ou transformar esse mesmo campo de forças, no qual se podem "engendrar as estratégias dos produtores, a forma de arte que defendem, as alianças que estabelecem, as escolas que fundam e isso por meio dos interesses específicos que aí são determinados" (Bourdieu, 2004, p. 22-23). Desse modo, pode-se dizer que aqueles pensadores e militantes católicos brasileiros que atuaram nos mais diversos campos sociais de luta disputaram posições, elaboraram propostas, circularam ideias e estabeleceram relações de poder. Paulo Freire (1921-1997) é exemplo eloquente desse engajamento católico militante no campo científico da educação, ao formular uma "pedagogia da ação" ela- 
borada a partir da sua própria experiência de vida com a realidade precária da população empobrecida e das suas leituras ressignificadas da filosofia política de Jacques Maritain (1881-1973) e da filosofia da ação de Emmanuel Mounier (1905-1950).

Há, de fato, que se fazer um esforço constante buscando refletir sobre as relações entre o pensamento e a ação católica no Brasil e em França, sobre o papel das instituições para reduzir os conflitos sociais e sobre a insuficiência da ideia de crescimento econômico em relação à ideia de desenvolvimento humano aplicado a todas as dimensões dos sujeitos. O pós-1945 se apresenta como essa nova condição emergencial e expõe um contexto que deve ser analisado, segundo pressupostos da metodologia genealógica foucaultiana, a partir dos estados de forças que marcaram o aparecimento de paradigmas, discursos e práticas: "A história, genealogicamente dirigida, não tem por fim reencontrar as raízes de nossa identidade, mas ao contrário, se obstinar em dissipá-la; ela não pretende demarcar o território único de onde viemos, essa primeira pátria à qual os metafísicos prometem que nós retornaremos; ela pretende fazer aparecer todas as descontinuidades que nos atravessam" (Foucault, 1979, p. 34 e 35$)$.

É preciso, portanto, construir uma genealogia do catolicismo social brasileiro do pós-1945 perspectivada como um movimento heterogêneo e por isso descontínuo, polissêmico, plural, de muitas matrizes com seus usos diferenciados, contraditados e dissipados e, ao mesmo tempo, atuante nos espaços públicos e institucionais, buscando traçar a influência e a interferência das múltiplas relações de poder e de força sobre a vida das pessoas. Na genealogia das relações de poder, Foucault também se preocupa em problematizar acerca das interinfluências e das relações de poder voltadas à produção do conhecimento e da verdade no campo das ciências e na institucionalização de práticas político-sociais: "Há um combate 'pela verdade' ou, ao menos, 'em torno da verdade' entendendo-se que não se trata de um combate 'em favor' da verdade, mas em torno do estatuto da verdade e do papel econômico-político que ela desempenha. É preciso pensar os problemas políticos dos intelectuais não em termos de 'ciência/ideologia', mas em termos de 'verdade/poder"' (Foucault, 1979, p. 13).

Paulo Freire, inserido no campo em disputa das ciências da educação, atuará em direção à produção da verdade e de um conhecimento pedagógico referenciado nos paradigmas da economia humanista católica. 


\section{Militantes Católicos EM EsPaÇOS PÚBLICOS E NOS CAMPOS DE PODER}

Como se sabe, a exploração do Terceiro Mundo ganhou uma severa crítica da Igreja católica oficial com as encíclicas papais de João XXIII (Mater et Magistra) e de Paulo VI (Populorum Progressio), mostrando o abuso do capitalismo liberal e reconhecendo na análise marxista uma ferramenta útil para a reelaboração de uma Teologia voltada ao desenvolvimento econômico e humano dos povos. A inauguração de uma ética econômica humana após a Segunda Guerra Mundial, construída no diálogo ora amistoso ora conflitivo entre catolicismo e comunismo, trouxe à cena a necessidade de reorganização do sistema capitalista em vista do bem-estar social de todos os povos.

No entanto, mais que a elaboração de um pensamento ético-religioso que serviu relativamente de base à nova ordem econômica, houve a organização clara de um movimento interno da Igreja católica no Brasil em interferir de maneira engajada e militante nos mais diversos espaços sociais e políticos em vista do diagnóstico, planejamento e desenvolvimento socioeconômico do país (Souza, 2015). Nas décadas de 1950 e 1960, a Igreja católica no Brasil, representada por grupos católicos de vanguarda, passou a atuar de modo mais engajado nos mais diversos campos de poder da sociedade. E foram muitos os pensadores católicos, políticos do Partido Democrata Cristão (PDC), sindicalistas, educadores, padres, estudantes universitários e outros atores católicos que buscaram consolidar um novo referencial vanguardista. Esse catolicismo militante e engajado produziu um impacto e exerceu um efeito significativo sobre todo o sistema político, econômico e educacional brasileiro do período. Segundo Alfredo Bosi, "O catolicismo brasileiro realmente começava a ser progressista nos anos 1950, sob a liderança intelectual de Alceu Amoroso Lima e a liderança política de André Franco Montoro, colaborador do padre Joseph Lebret desde a primeira hora" (Bosi, 2012, p. 255).

Uma geração de militantes católicos no Brasil contribuiu, pois, para a fundação do Partido Democrata Cristão (PDC), para a definição das políticas de governo apresentadas pelas comissões federais e estaduais de desenvolvimento social, econômico, educacional e habitacional, para interferência em sindicatos urbanos e rurais e para a difusão de um pensamento intelectual humanista e leitor crítico do marxismo. Esses sujeitos engajados, capazes de operacionalizar um ethos de maneira atuante e influente nos campos de poder da sociedade, construíram uma rede de relações de força extremamente significativa. 
A historiografia tem pouco se debruçado sobre esse fenômeno social, tampouco percebendo-o como um movimento social propriamente dito que se estruturou a partir do campo religioso católico e que permeou as relações político-sociais dos outros campos articuladores de poder da sociedade. Não se pode esquecer que a geração de militantes católicos, ao forjar nas primeiras décadas do pós-1945 os instrumentos desse engajamento, reposicionou a Igreja oficial na perspectiva da responsabilidade social e participativa com as carências humanas e dialogou fortemente com os comunistas em vista de uma proposta economicamente mais comunitária e solidária. De fato, como destaca Bourdieu, dentro dos campos e, em específico, no campo religioso católico do pós-1945 no Brasil, percebem-se "relações de força entre os agentes e a instituição que lutam pela hegemonia, isto é, pelo monopólio da autoridade, que concede o poder de ditar as regras e de repartir o capital específico do seu campo de poder" (Bourdieu, 1983, p. 114).

No processo de atuação desses novos militantes no campo católico e em sua relação com o campo político verifica-se, na Europa e na América Latina, a formação dos partidos democratas cristãos. No Chile ganharam mesmo as eleições presidenciais. Paulo Freire, na época do seu exílio no Chile, trabalhou por 5 anos para o movimento de reforma agrária da Democracia Cristã. Em suas memórias, Pablo Neruda refere-se ao Partido Democrata Cristão nestes termos:

O Partido Democrata Cristão me interessou muito desde seu nascimento. Surgiu quando um grupo reduzido de intelectuais católicos formou uma elite maritanista e tomista. Este pensamento filosófico não me preocupou [...] A velha hierarquia eclesiástica esteve a ponto de dissolver o novo partido. Só a intervenção de um bispo precursor os salvou do suicídio político [...]. A declaração do prelado de Talca permitiu a sobrevivência do grupo que com o tempo se transformaria no partido político mais numeroso do Chile. (Neruda, 1980, p. 363-364)

No Brasil, a democracia cristã foi fundada em julho de 1945 e veio a denominar-se "Partido Democrata Cristão" (PDC). Sua estrutura tinha por base o "Partido Democrata Cristão" italiano, liderado por Alcide de Gasperi, expoente do catolicismo romano, e mais, a "União Democrática Cristã" da Alemanha, o "Partido Social Cristão" da Bélgica e o "Partido Popular Austríaco". Para Alceu Amoroso Lima, um dos fundadores do PDC e uma das lideranças leigas do catolicismo no Brasil, "Não se tratava de uma iniciativa confessional, mas de um movimento de fraternidade cívica inspirado nos princípios políticos 
que a Igreja propõe a seus filhos e que uma sã filosofia do homem e da sociedade descobre e aprofunda" (Lima, 1945, p. 105).

Tratava-se - sob os pressupostos da obra Humanismo Integral, publicada em 1936 pelo católico francês Jacques Maritain - da constituição de um Estado secular, democrático, leigo, pluralista e tolerante, constituído por católicos engajados politicamente e outros agentes sociais, avessos aos regimes liberais tradicionais, às democracias burguesas e aos regimes totalitários. Tinha-se por finalidade criar democraticamente uma ordem temporal-estatal penetrada pelo humanismo integral cristão:

Este novo humanismo, sem medida comum com o humanismo burguês e tanto mais humano quanto não adora ao homem, se não que respeita, real e efetivamente, a dignidade humana e reconhece direito às exigências integrais da pessoa, o concebemos orientado para uma realização sócio-temporal daquela atenção evangélica ao humano que deve não só existir na ordem espiritual, mas encarnar-se, tendendo ao ideal de uma comunidade fraterna. (Maritain, [1936]1965, p. 6)

Para Jacques Maritain, para seus seguidores católicos engajados e para alguns simpatizantes da vertente comunista no Brasil e na América-latina, a democracia cristã era mais que um sistema de governo pela maioria, era uma maneira participativa de viver em sociedade, construída pelo princípio vital da justiça social e do amor solidário a todas as pessoas e sob a condição de uma filosofia política do desenvolvimento humano integral, pautada no heroísmo militante de ser cristão. Por essa razão, todo ambiente social deveria permitir a comunicação socialmente ampla entre as pessoas para que elas viessem a desenvolver plenamente suas habilidades, reivindicar progressivamente seus direitos e garantir a sua dignidade (Maritain, [1942]1945).

Era a primazia da existência sobre a essência, da ação como revelação do ser. De fato, para Maritain, a pessoa é um ser que se revela somente por uma prática político-social democrática em vista de seus direitos humanos na história. Será, pois, esse valor fundamental de se constituir e de agir como pessoa livre em todos os espaços e contextos sociais que lhe garantirá os direitos em prol do progresso social e de melhores condições de vida. Toda democracia dita civilizada, segundo Maritain, deveria aprovar em sua carta magna e perseguir em sua ação política os direitos e as liberdades da pessoa humana, os direitos e as liberdades políticas, os direitos e as liberdades sociais com as suas responsabilidades correspondentes (Maritain, 1950). O norte apontado pela filosofia política de Maritain privilegia, pois, a pessoa no seu exercício de agir 
e de participar democraticamente nos espaços sociais e institucionais. E a conceituação operante da noção de pessoa humana sobre a realidade social constituiu a contribuição principal de Jacques Maritain ao grupo que formulou a Declaração Universal dos Direitos Humanos da ONU em 1948 e do qual ele fez parte, bem como orienta e fundamenta, em parte e ainda hoje, a adoção desse conceito pelos comitês da ONU como critério basilar para julgar a civilidade das nações.

A Democracia Cristã, ou a "nova democracia", foi, de fato, um dado novo no sistema de forças políticas e no processo de constituição e fortalecimento de uma militância católica enquanto movimento social e político do pós-guerra. Esses militantes católicos foram porta-vozes de uma causa que se expôs e se constituiu por opção mais prática que teórica, mas que não saíram vencedores. A voragem industrialista dos anos 1970, acompanhada de sua crise; a resposta tardia do Concílio Vaticano II ou mesmo seu recuo discursivo ao modelo de desenvolvimento econômico que vinha sendo gestado por esse grupo; e os golpes militares latino-americanos, incluindo o brasileiro, vieram a desarticular esses agentes, suas redes, sua Teologia e seu ethos.

A história desses militantes em suas relações de poder é a história daqueles sujeitos saídos do catolicismo mais tradicional que descobriram os limites e os impasses do seu momento sociorreligioso e refutaram a aceitá-lo. Eram os nascidos sob a égide de um catolicismo antimodernista, assistencialista, preso às relações de subserviência ao Vaticano e seu processo de romanização. Mas eram os mesmos que sentiram os ares da renovação teológica dos anos 1920, o nascimento dos movimentos da Ação Católica especializada (JEC, JUC, JOC) e as experiências da democracia cristã europeia e da sua relação com o mundo moderno e o catolicismo social francês. Eles vinham de um catolicismo intransigente (Poulat, 1977), o qual recusava o materialismo contemporâneo que negava a transcendência e que acabava impossibilitando o laço social. O contexto da Segunda Guerra Mundial e seus abalos trágicos advindos de um sistema de valor social e religioso que o formou e o manteve por largos anos estava quebrado e sem sentido. Havia um espaço vazio de significados, teorias, práticas e inovações a serem estabelecidas. Esses católicos foram se distanciando progressivamente de suas bases de valor ético, e assim se descobriram solidários de uma modernidade que tinham recusado. E as exigências práticas da nova experiência social precederam às reformulações doutrinais, colocando-os inicialmente distantes do catolicismo oficial e tornando-os "invisibilizados" pela hierarquia católica. Ao se referir às experiências sociais dos padres operários franceses, o historiador Charles Suaud mostra, por exemplo, que "era se 
expondo às fatigas, aos riscos de trabalho assim como às sanções por vezes mortais motivadas por erros técnicos, que os padres operários se colocaram em situação de conhecer uma nova contrainculcação corporal, oposta àquela frequentemente recebida nos seminários" (Suaud, 2004, p. 42).

É preciso, portanto, admitir a estranheza desse movimento e desse militante católico ao se constituir na sua relação com o mundo moderno no qual ele se engajará e, após isso, admitir também a estranheza desse movimento e desse mesmo militante ao se apresentar de forma tão capilar e enraizada na vida social e política brasileira a partir de 1945. Afinal, esses militantes católicos recusavam a herança liberal do mundo moderno e eram absolutamente institucionais. Eram saídos dos bancos universitários, de uma elite empresarial, de sindicatos rurais e de operários, de escolas católicas, de partidos políticos e da hierarquia católica. Eram protagonistas "convertidos" de um novo mundo que se abria à sua frente e se alinhavam no campo católico ao pensamento democrata cristão constituído na Europa e na América Latina. A matriz de um discurso católico francês e a vivência em França foram de grande influência, marcadamente para aqueles militantes do movimento "Economia e Humanismo", fundado pelo padre Louis-Joseph Lebret, da ordem religiosa dominicana.

Estudando a obra de Marx, o padre Joseph Lebret incorporou à doutrina social cristã a noção de mais-valia: daí a sua crítica à economia liberal. Economia Humana parte das necessidades do trabalhador e não dos cálculos de lucro do empresário. As equipes de pesquisa (surveys) do movimento Economia e Humanismo estudaram as condições de vida dos bairros pobres de cidades francesas depois da Segunda Guerra Mundial. Vindo ao Brasil, Lebret orientou levantamentos semelhantes em São Paulo, Rio, Belo Horizonte e Recife, formando pesquisadores que trabalharam junto às prefeituras locais. Visitou 60 países do Terceiro Mundo. Por indicação de D. Helder Câmara, Paulo VI o designou para a função de perito em questões de desenvolvimento social no Concílio Vaticano II. Redigiu, pouco antes de falecer (1966), a encíclica Populorum Progressio. (Bosi, 2012, p. 249)

Padre Lebret esteve diversas vezes no Brasil, incentivando a constituição de uma militância católica, a edificação de uma democracia cristã, a aproximação com a análise marxista, a participação nos espaços políticos e o desenvolvimento econômico pela aplicação de métodos sociológicos específicos. Ao fundar o movimento Economia e Humanismo, Lebret elaborou uma economia humana em que a base científica da economia política e das ciências humanas 
renovaria a doutrina social da Igreja. No contato com os países de "Terceiro Mundo", dentre eles o Brasil, foi possível elaborar as teorias econômicas do desenvolvimento humanista e de um pensamento político, estimulando a ida de católicos à França para conhecerem as experiências e estratégias adotadas no processo de desenvolvimento socioeconômico (Pelletier, 1996).

Trata-se de um pensamento político desenvolvimentista em que o catolicismo social oferecia respostas compatíveis com as exigências metodológicas da ciência moderna e com as exigências políticas da democracia liberal. Frequentemente negligenciada pela literatura militante, essa especificidade católica de um engajamento pós-1945 exige uma melhor compreensão. Afinal, o processo de destruição das solidariedades tradicionais na sociedade brasileira pelo desenvolvimento capitalista exigiu uma resposta da Igreja católica, uma vez que ela sempre esteve ligada de alguma forma aos desdobramentos políticos do país e se constituiu como uma das bases culturais da formação do povo brasileiro. Havia a necessidade de um posicionamento e reposicionamento do seu papel social. Um grupo de militantes católicos aflorou, alimentou-se também na experiência feita em solo francês e se lançou engajadamente em uma ação comunitária de influência política sob bases científicas de forte presença nos espaços sociais mais diversos (operários e rurais) e de aproximação com os comunistas, alcançando a oficialidade da Igreja a ponto de provocar o Concílio Vaticano II. Essa história de originalidade católica na sociedade contemporânea e brasileira é a própria história de mudança da Igreja oficial e hierárquica que incorporou muito desse processo ou que muito recuou.

Esses sujeitos militantes participavam ativamente e de maneira engajada em espaços político-sociais. Atuando nos mais diversos campos sociais interferiam nas políticas governamentais e estabeleciam uma relação de poder capaz de criar demandas e oferecer soluções. O envolvimento efetivo desses sujeitos alcançava lugares diversos e eles atuavam fortemente em suas organizações. E esse militante católico de feições sociais pós-1945 está para além do formato baseado no assistencialismo e na caridade, o que é comumente atribuído às atividades religiosas. Esses militantes participaram no sentido de liderar organizações políticas e partidárias, sindicais, associações culturais e espaços escolares e que, por meio de uma postura crítica e discursos comuns, agiram diretamente no sistema social em vista de transformá-lo.

Identifico, inicialmente, na presença dos frades dominicanos em São Paulo um cenário da constituição formativa e educativa do que seria e viria a ser esse militante católico dos primeiros tempos do pós-1945. O vínculo estreito ao campo religioso aos poucos ia se abrindo e se articulando com outros 
campos (político e educacional). Esses religiosos ensaiaram um movimento de convergência com movimentos que buscavam uma educação baseada no humanismo integral e de renovação nos sistemas secundário e universitário brasileiros, mantendo-se muito ligados aos dominicanos franceses. Segundo Frei Betto,

As novas vocações dominicanas brasileiras eram enviadas à França para cursar Filosofia e Teologia. Imbuíam-se da filosofia de Jacques Maritain e da teologia do padre Congar; do pensamento militante de Emmanuel Mounier e dos exemplos de ação conjunta de marxistas e cristãos na resistência francesa. Esse influxo renovador encontrou, no Brasil, a terra fértil arada pela atuação pioneira de dom Helder Câmara, fundador da CNBB e incentivador da Ação Católica, respaldada pelas ideias arejadas de Alceu Amoroso Lima. Os jovens dominicanos retornados da França se envolviam com o mundo operário e o movimento estudantil, interessados em formar lideranças leigas. Nossos conventos tornaram-se oficinas de novas ideias e propostas. Em São Paulo, Frei Carlos Josaphar atraía o público a seus cursos sobre justiça e doutrina social da Igreja. Reunira uma equipe de conceituados jornalistas e fundara o tabloide BRASIL URGENTE, que seria fechado pela ditadura. (Betto, 2006, p. 69)

Gómez de Souza (2003) lembra também que em 1959 os dominicanos e universitários da JUC seguiam realmente as propostas de Jacques Maritain, mas, logo no começo da década seguinte, o personalismo de Emmanuel Mounier é que serviria de inspiração. Fundador em 1932 da revista Esprit, Mounier fez uso desse instrumento, associado a outros pensadores, dentre eles Maritain, para divulgar o pensamento de uma nova civilização nascida de uma revolução personalista e comunitária. Sua principal obra, O personalismo (1950), exerceu enorme influência no pensamento político das nações ocidentais, dando força às ações humanistas em toda a segunda metade do século XX e orientando os ideários políticos - da democracia cristã progressista à democracia de inspiração socialista. O personalismo de Mounier consistia em uma oposição frontal ao individualismo. A preocupação dessa revolução personalista era descentralizar o indivíduo para colocá-lo em uma perspectiva aberta à construção da pessoa humana em comunidade. Essa pessoa surgiria como "uma presença voltada para o mundo e para as outras, sem limites, misturadas com elas em uma perspectiva comunitária. As outras pessoas não a limitam, fazem-na ser e crescer. Não existe senão para os outros, não se conhece senão pelos outros, 
não se encontra senão nos outros [...] A verdade de cada um só existe quando em união com todos os outros" (Mounier, [1950]2004, p. 45-47, 86-87).

Se Maritain havia contribuído com movimentos em países como o Chile, a Venezuela e mesmo a seção paulista do PDC, a ação dos militantes da JUC, principalmente em Belo Horizonte e São Paulo, iria recorrer ao pensamento de Mounier. Um compromisso que, aos poucos, foi se revelando como personalista e socialista.

Queríamos deixar-nos penetrar pelas aspirações de uma nova consciência histórica e apostávamos, com Emmanuel Mounier, num socialismo personalista e comunitário; denunciavam-se o sistema capitalista desigual e o subdesenvolvimento, dependente e associado, como se diria um pouco mais adiante; reformas de base, pediam dirigentes estudantis e sindicais; começava a descoberta da cultura popular: Paulo Freire, conscientização, MEB, MCP de Recife, CPC da UNE; valorizavam-se o saber do povo e seu processo pedagógico, da consciência mágica à consciência crítica. (Gómez de Souza, 2003, p. 176)

O grupo de estudantes dominicanos comungava os impasses e as opções de expressiva parcela de uma geração universitária. Eram alunos da Universidade de São Paulo (USP) e alguns discípulos do padre Lebret (Betto, 2006, p. 78). Sabe-se que o superior dominicano do convento de São Paulo, Frei Romeo Dale, posteriormente superior do convento do Rio de Janeiro, foi quem estimulou a leitura da filosofia da ação de Mounier e acolheu e introduziu Lebret no Brasil, criando as Equipes de Economia Humana e traduzindo alguns de seus livros para o português (Principes pour l'action). Dale também se tornou o coordenador nacional da Juventude Universitária Católica (JUC), fazendo difundir entre os universitários métodos de pesquisa e diagnóstico social. As cartas trocadas entre Dale e Lebret, arquivadas na Biblioteca dos dominicanos em São Paulo e no Rio de Janeiro, reforçavam essa relação e mostravam a necessidade de disseminar os princípios de uma nova Ação Católica no Brasil de forma organizada e sistematizada. Segundo Alfredo Bosi,

Lebret encontrou no Brasil uma sociedade meio tradicional, meio moderna, na qual o sentido da palavra comunidade não soava como uma reminiscência medieval. Uma sociedade que conhecia ilhas de solidariedade vicinal tanto em áreas rurais como em bairros pobres das metrópoles que começavam a inchar com a migração. Era possível entrar nos cortiços e nas favelas, conversar com os moradores e ouvir de sua boca as suas necessidades e sentir o calor da sua generosida- 
de. O Brasil deu à Economia Humana de Lebret uma injeção de ânimo. E uma perspectiva nova. (Bosi, 2012, p. 260)

Refiro-me aqui, portanto, à constituição de um engajamento católico de feições distintas e originais e que nasceu da aproximação com o marxismo e com o catolicismo social francês, que adquiriu a dimensão social com as experiências da JOC, JEC e JUC importadas da Bélgica, que se fortaleceu com as palavras do papa João XXIII e que alcançou o chão da fábrica e o mundo rural em sua condição mais sub-humana.

A "cultura católica brasileira" e a "cultura católica francesa" aproximaram-se pela experiência acumulada e refletida da realidade social. Essa experiência social comum e relacional permitiu uma memória coletiva, relações de solidariedade e uma afinidade eletiva que se deram, pois, por meio da narração dos lugares e dos acontecimentos da experiência vivida, rememorada e solidária. (Souza, 2009, p. 291)

Posso previamente apontar para cinco grupos específicos de militantes católicos brasileiros no pós-1945 e que realizaram experiências de vivência social em França ou que foram influenciados pelo pensamento católico francês: os intelectuais (exemplos: Alceu Amoroso Lima, Antônio Queiroz Filho, Álvaro Vieira Pinto, Alberto Guerreiro Ramos); os políticos (exemplos: André Franco Montoro, Plínio de Arruda Sampaio, Paulo de Tarso); os sindicalizados (exemplos: Mario Carvalho de Jesus - advogado do sindicato dos metalúrgicos de São Paulo, Vicente Marota Rangel e Nelson Abrão - membros da direção do sindicato da indústria de cimento Perus e que foram fazer experiência de sindicato, de gestão comunitária e de trabalho na fábrica de caixas de relógio em Boimondau, organizada pelo padre Joseph-Lebret); os educadores (exemplos: Germano Coelho, Paulo Freire na sua relação com o humanismo integral do católico francês Jacques Maritain e Emmanuel Mounier), e os religiosos (exemplos: Dom Hélder Câmara, Dom Jorge Marcos de Oliveira, Dom Antônio Fragoso, Frei Romeo Dale).

Mas como esses militantes católicos tornaram-se democratas cristãos engajados? Como se constituíam em grupos de liderança e de interferência? Quais suas origens sociais e políticas? Quais espaços ocuparam e que tipo de interferência realizaram em determinados campos de poder? Quais relatos deixaram? Com base em qual pensamento econômico, pedagógico e teológico se elaboraram ideias, vertentes e metodologias? Há um universo de questões a serem feitas e respondidas, a serem coletadas, organizadas e narradas. 


\section{Paulo Freire: UM EdUCAdor da ENCARnaÇão SOCIAL E MILITANTE CATÓLICO}

Trazer muito brevemente a trajetória de vida de Paulo Freire como católico engajado no período pós-1945 ajuda a exemplificar a situação inter-relacional daqueles outros militantes católicos, na busca de se inserirem no interior dos outros campos sociais de poder e neles disputar o controle, a legitimação dos bens produzidos (Bourdieu, 2004) e a produção de verdade (Foucault, 1979). Nesse sentido, Freire insere-se no campo das ciências da educação, disputando a legitimidade de atuação entre os que têm posições dominantes no campo e produzindo verdade. Essa atuação mostrou a relevância da educação libertadora como dispositivo privilegiado no processo de conscientização social, de difusão mais ampla do pensamento democrático cristão em sua relação com a análise marxista, de conversão dos sujeitos à ação participativa e de transformação da realidade a partir do desenvolvimento de uma economia humanista.

Quando Freire havia completado 8 anos de vida, a crise financeira de 1929 lançou sua família em direção à miserabilidade, à fome e à percepção de uma pobreza silenciosa, de religiosidade inoperante e "incomprometida" com a realidade de sofrimento, incapaz de se integrar com as soluções de seus problemas sociais. No ano seguinte, ao perder o pai militar de confissão espírita e a quem admirava pela postura sempre dialógica, assumiu deliberadamente a cultura católica da mãe, e isso iria influenciá-lo de maneira permanente. Esse dilema da sua infância o fez reconhecer a importância de "estar no lugar do outro" e "ser com o outro" (Freire, 1978). E é por essa razão que no processo educativo freiriano não basta entender e conhecer, é preciso vivenciar e experimentar as realidades "do outro com o outro", a partir de uma atitude sensível e dialógica de não o violentar na sua cultura própria, na sua dimensão volitiva de querer, de optar, de escolher e de se expressar.

A sua experiência de infância e a influência do humanismo integral de Jacques Maritain, do personalismo comunitário de Emmanuel Mounier e do marxismo serão fundamentais para conceituar e teorizar essa sensibilidade pelo desvalido, pelo oprimido e pelo despossuído enquanto práxis de transformação e libertação das condições de empobrecimento e dependência econômica.

Nesta época, devido às distâncias, que, ingenuamente, não podia compreender, entre a vida mesma e o compromisso que ela exige, e o que diziam os padres nos 
seus sermões dominicais, afastei-me da Igreja - nunca de Deus - por um ano, com o profundo sentimento de minha mãe. Voltei a ela através, sobretudo, das sempre lembradas leituras de Tristão de Athayde, por quem, desde então, nutro inabalável admiração. A estas imediatamente se juntariam as leituras de Maritain, de Bernanos, de Mounier e outros. (Freire, 1978, p. 7)

Como corrobora Francisco Weffort no prefácio à obra de Paulo Freire Educação como prática da Liberdade, escrita entre os anos de 1964 e 1965 no exílio em Chile e publicada no Brasil em 1967, a matriz de pensamento de Freire é, deveras, católica. Sua filiação cristã é explícita, e, escreve Weffort,

Existir, para Freire, é uma dialogação do homem com o homem, do homem com seu Criador. É essa dialogação do homem sobre o seu contorno e até sobre os desafios e problemas que o faz histórico. [...] Os reacionários não podiam compreender que um educador católico se fizesse expressão dos oprimidos e menos ainda podiam compreender que a cultura levada ao povo pudesse conduzir à dúvida sobre a legitimidade de seus privilégios. Preferiram acusar Paulo Freire por ideias que não professa a atacar esse movimento de democratização cultural pois percebiam nele o gérmen da revolta. (Freire, 1967, p. 11 e 14)

A opção inicial de Freire é pelo humanismo cristão de Jacques Maritain, um dos propositores da Declaração Universal dos Direitos Humanos de 1948, na qual a pessoa humana é apresentada como um ser em construção na história e membro solidário voltado à formação integral das suas aptidões humanas e ao bem comum. Por essa razão, Freire adverte para o perigo de uma educação técnica e especializada que suprime a visão integral da pessoa humana e que conduz a uma animalização progressiva da vida.

Se concordamos em que o animal é um especialista - diz-nos Maritain em La Educación en Este Momento Crucial, p. 39 - e especialista perfeito, já que toda a sua capacidade de conhecer está limitada a executar uma função determinadíssima, haveremos de concluir que um programa de educação que aspirasse só a formar especialistas cada vez mais perfeitos em domínios cada vez mais especializados, e incapaz de dar um juízo sobre um assunto qualquer que estivesse fora da matéria de sua especialização, conduziria, sem dúvida, a uma animalização progressiva do espírito e da vida humana. (Freire, 1967, p. 98)

Ao fazer também a opção pelo personalismo comunitário de Emmanuel Mounier, Freire vai dizer que o vínculo unitivo interpessoal e engajado é que 
situaria o sujeito na história, pois seria a ação humana no mundo, nos diversos contextos sociais da vida e na experiência comunitária que daria consciência, personalidade e existência à pessoa humana: "Em Emmanuel Mounier, o liame entre pessoa e a comunidade é tão orgânico que tudo o que se diz da pessoa pode ser transposto e dito da comunidade" (Freire, 1967, p. 50). Por isso, a própria filosofia de Mounier se converte para Freire em pedagogia da vida comunitária ligada a um despertar da pessoa, mobilizando-a a se engajar no seu entorno social e transformando o mundo à sua volta. Não é por outra razão que a educação não pode se reduzir a uma simples transmissão da cultura por meio de livros, senão por um processo de conhecimento dialógico-crítico da pessoa com a sua realidade social. Em assim sendo, a democracia, dentro da concepção comunitário-personalista freiriana, seria a representação dos pluralismos sociais na qual todas as pessoas teriam acesso aos benefícios gerados por elas, já que todos também seriam coproprietários dos meios de produção e realizariam a cogestão, fazendo referência ao pensamento humanista cristão e às encíclicas papais de João XXIII (Mater et Magistra) e Paulo VI (Populorum Progressio). Freire, ao ingressar em 1947 como docente na Escola de Serviço Social de Pernambuco, lecionando Filosofia da Educação, "reconheceu mesmo ter sido a Escola de Serviço Social um dos polos de influência de seu pensamento pedagógico e social. [...] Dominava ali uma ciosa defesa de princípios e valores, próprios da doutrina social da Igreja" (Gadotti, 1996, p. 90).

Mas Freire faz um movimento de aproximação e de crítica em relação ao catolicismo. Ele tem a nítida percepção do poder do campo católico no Brasil de interferir e de se imiscuir em outros campos: intelectual, econômico, político e educacional. Por essa razão, critica aquele catolicismo reformista que tenta apenas harmonizar as classes e que busca o entendimento mútuo de base moral. Freire (1978) fala que muitos grupos latino-americanos sérios caíram nessa consciência sem ação.

O olhar crítico e analítico de Freire como intérprete do Brasil nasce, portanto, de sua experiência de vida, amplia-se em razão das leituras de vivência e conversão de Jacques Maritain, Emmanuel Mounier e Alceu Amoroso Lima e consolida-se pelas experiências dos padres operários nas fábricas e de certas lideranças católicas nas zonas rurais, nas favelas, nas comunidades carentes e nos espaços escolares de periferia. Nesses termos, Freire também se "converte" em católico engajado e militante.

O conceito de conversão do pós-1945 (Suaud, 2004), adensado pela matriz do existencialismo cristão-humanista, vem de este tornar-se "outro" pela experiência e modo de vida "do outro" e "com o outro", pelo sentir e viver o sofri- 
mento "do outro" e "com o outro" (Freire, 1967), estabelecendo uma relação direta com o socialismo comunitário de Mounier: "É necessário conhecer o povo e para isso não basta olhá-lo de fora. Assim, para perceber o sentido deste conhecimento do povo é preciso não somente agir para o povo, ocupar-se de obras que visam ao povo humilhado e desprezado, mas ser com, existir com o povo, sofrer e comungar com seu destino" (Mounier, [1950]2004, p. 62).

O contexto do pós-1945 permitiu, pelo pacto populista e democrático, uma aproximação desses agentes "convertidos" (protestantes, católicos, operários, padres, intelectuais, sindicalistas, educadores, políticos) em espaços comuns de experiência, instituindo um período de transição desafiadora para que esses agentes também começassem a mudar de uma visão idealista e de uma consciência moral para uma visão dialética e transformadora da realidade, como havia sugerido a filosofia político-democrática de Maritain e a filosofia da ação do personalismo comunitário de Mounier. De acordo com Freire em Os cristãos e a libertação dos oprimidos (Freire, 1978), "nesse processo aprenderam muito, não só na sua ação junto ao povo, mas também com o exemplo de desprendimento e de coragem de boa parte da juventude" (Freire, 1978, p. 41). Esses agentes convertidos, portanto, se deram conta de que a realidade é um processo contraditório e conflitante, expressão histórica do embate das contradições reais da vida. Essa posição exigiu uma análise crítica das estruturas sociais e o emprego das ciências político-sociais como se havia dito anteriormente a se fazer referência ao padre Lebret.

Essa nova noção de conversão remete, assim, a uma atitude de ação, presença, engajamento e militância nos espaços não vivenciados, bem como a uma atitude de radicalismo revolucionário. Segundo o próprio Freire, "na atualidade brasileira, as posições radicais, no sentido positivado que lhes damos, vinham sendo assumidas, sobretudo, se bem que não exclusivamente, por grupos de cristãos para quem a 'História', no dizer de Mounier, tem sentido" (Freire, 1967, p. 50). Esses cristãos católicos engajados e militantes eram preferencialmente jovens dos movimentos de luta e mobilização da Igreja em transição (JUC, JEC, JOC, Ação Popular, MEB, CEBs). Por essa razão, a casa paroquial começa a perder sua condição de centralidade e outros territórios começam a fazer parte da cultura paroquial: a favela, a escola, o sindicato, a universidade, o círculo de cultura, a fábrica, a periferia, a roça.

De fato, o pensamento e a práxis de Paulo Freire em Educação como prática da liberdade estavam colados ao idealismo político-democrático de Maritain e à filosofia da ação de Mounier, e não às posturas revolucionárias marxistas. 
A produção em série faz do trabalhador um ser passivo. Medroso. Ingênuo. Daí, a sua grande contradição: a ampliação das esferas de participação e o perigo de esta ampliação sofrer distorção com a limitação da criticidade. A solução, na verdade, está na aceitação da realidade, na solução objetiva de seus problemas e na humanização do homem. Apreciamos as análises de Mounier, neste sentido. Emmanuel Mounier - Sombras de Medo Sobre o Século XX. (Freire, 1967, p. 89)

Por esse motivo, o radical revolucionário não deveria deter a história nem tampouco antecipá-la, "estes seriam os sectários de direita e de esquerda ativista" (Freire, 1967, p. 60). Neste ponto, Freire se distancia do marxismo e se aproxima ainda mais das posturas do catolicismo social. Vê o radical revolucionário militante como aquele que interfere e interage com a realidade em vista de transformá-la, libertá-la, sem dar um entendimento teleológico, fechado e certo ao futuro. Pois o futuro, nessa acepção, é uma construção, um fazer-se no processo, no caminho, na travessia, sem uma previsão senão aquela da libertação dialógica ou da libertação em processo inacabado e contínuo. "Só na convicção permanente do inacabado podem encontrar o homem e as sociedades o sentido da esperança. Quem se julga acabado está morto" (Freire, 1967, p. 61).

Esse compromisso com a existência personalista mounieriana é entendido por Freire como um processo dinâmico que implica um diálogo participativo e transformador das suas relações com o mundo (exterioridade), com os outros sujeitos (alteridade) e com o Criador (transcendentalidade). Nesse sentido, considerando os pressupostos maritanistas e mounierianos de Freire, a intransitividade social representa um "incompromisso" do sujeito com sua existência em direção ao desenvolvimento pleno e integral. Somente pelo diálogo, participação e integração com a realidade social o ser humano é capaz de promover uma transitividade para uma sociedade humana e integralmente desenvolvida. Em um primeiro estágio essa transitividade é ingênua, caracteriza-se pela simplicidade na interpretação dos problemas e se deixa conduzir pela interpretação de outros. Em um segundo estágio se torna uma transitividade crítica (conscientização, inserção, participação e integração transformadora para o desenvolvimento humano pleno e integral), fruto de uma educação voltada à responsabilidade participativa, social e política, caracterizando-se pela profundidade na interpretação e nas soluções dos problemas.

A própria concepção de "tomada de consciência", de "conscientização" e de "desenvolvimento social” é atribuída por Paulo Freire aos intelectuais católicos do Instituto Superior de Estudos Brasileiros (Iseb), vinculado ao Ministério da Educação e Cultura (MEC), especialmente Álvaro Vieira Pinto e 
Alberto Guerreiro Ramos, bem como sua difusão em outras línguas por Dom Hélder Câmara (Freire, 1980, p. 25). Conforme Bresser-Pereira,

Essa concepção de conscientização proposta por Paulo Freire é provavelmente a estratégia política revolucionária por excelência da esquerda católica na América Latina. Nascida de um católico, ela tem grande apelo nos meios católicos. O humanismo cristão que a inspira, seu caráter ao mesmo tempo neutro e ideológico, sua ênfase na liberdade e na responsabilidade, seu claro relacionamento com a "conversão", a prioridade que dá à mudança de mentalidade ao invés da mudança das estruturas. Todos esses aspectos têm um forte apelo para os católicos e ajudam-nos a explicar a adoção da conscientização como sua estratégia básica. (Bresser-Pereira, 2006, p. 128)

A ação pública de Freire, em consonância com a militância católica do período, deu-se por um processo de engajamento e de denúncia da ordem social injusta, fundamentado na autoridade máxima do papa João XXIII, em suas encíclicas Mater et Magistra (1959) e Pacem in Terris (1963). Assim como Emmanuel Mounier fora chamado de "o educador da encarnação social", o mesmo se pode dizer de Paulo Freire. Ele viveu esse engajamento social e essa militância encarnada nas suas experiências como diretor do Movimento de Cultura Popular (MCP), destacando-se por seu trabalho na área da educação popular, voltada tanto para a alfabetização de adultos e jovens como para a formação da consciência política. O MCP foi criado em 13 de maio de 1960, na gestão do prefeito do Recife, Miguel Arraes, a partir de encontros com vários intelectuais e educadores. A proposta que instituiu o movimento foi elaborada por Germano Coelho, que havia retornado ao Brasil após seu estágio doutoral no Movimento Peuple et Culture, em França. Segundo Germano, O MCP nasceu dessa influência vivida em França e da miséria do povo do Recife, "da lama, dos morros e alagados, onde crescem o analfabetismo, o desemprego, a doença e a fome. Fincam-se nas terras áridas do Nordeste. Refletem o seu drama, como síntese dramatizada da estrutura social inteira" (Coelho, 2012, p. 437).

O MCP e o próprio Freire influenciaram o Movimento de Educação de Base (MEB), instituição criada em 1961 pela Conferência Nacional dos Bispos do Brasil (CNBB), com sua cartilha de alfabetização voltada a uma educação libertadora. Para além de um trabalho social mais amplo, buscava-se conscientizar camponeses e operários sobre as possibilidades de se organizar coletivamente e transformar a realidade. No contato do MEB com as comunidades de 
trabalhadores e nas trocas de ideias o educando era levado a "converter-se" e a assumir o seu processo educativo com autonomia a partir de uma linha de reflexão e ação sobre suas necessidades concretas, tais como: acesso à assistência à saúde, a um trabalho digno, à habitação e ao universo cultural, refletindo sobre sua relação com o outro, com Deus, com a comunidade e com o Estado. A proposta era superar os níveis de marginalização, visando, segundo Mounier, "à libertação integral e ao desenvolvimento de uma mentalidade participativa em que as condições da existência material fossem mais bem distribuídas" (Freire, 1967, p. 97). Essa responsabilidade participativa recolocava o educando e, por extensão, o povo como agente de sua própria recuperação, porque a participação que interfere no mundo e com o mundo é um dado existencial, algo incorporado vivencialmente, que se integra ao seu contexto e o modifica, muda, transforma e faz de cada sujeito autor de sua própria libertação. Portanto, o fim da educação libertadora "não consistia em fazer, mas em despertar pessoas" (Mounier, [1950]2004, p. 129).

No Brasil do pós-1945 vivia-se, de fato, uma transitividade moderna: rádio, televisão, caminhão, avião, industrialização e mecanização do campo, ao mesmo tempo que um movimento popular instaurava também uma disposição ativista, reivindicativa, reformista e até revolucionária. Segundo insistia Freire,

Cada vez mais nos convencíamos de que teria o homem brasileiro de ganhar sua responsabilidade, participando, ganhando cada vez maior ingerência nos destinos da escola do seu filho, nos destinos de seus sindicatos, de sua empresa, através de agremiações, de clubes e de conselhos, ganhando ingerência na vida do seu bairro, de sua Igreja. [...] Assim, iríamos ajudando o homem brasileiro, no clima cultural da fase de transição, a aprender democracia, com a própria existência desta. (Freire, 1967, p. 100)

O processo educativo deveria, portanto, instaurar o método da ação participativa e transformadora da realidade que não se realizaria unicamente na tomada da consciência em espaços escolares, mas na radical transformação das estruturas sociais, em cujo processo se transformam as consciências. Por isso, educadores e educandos deveriam estar integrados e vinculados mediante sua presença engajada e atuante na sociedade. A educação devia, portanto, tornar a pessoa humana consciente de sua liberdade no mundo, estimulando a atitude crítica diante da realidade social. Palavras do cotidiano, como favela, fome e trabalho, deveriam ser discutidas no processo de aprendizagem para, na se- 
quência, se pensar no engajamento político e nas transformações das condições materiais da existência (Freire, 1967).

Freire assumiu essa sua parcela de responsabilidade participativa na busca pelo desenvolvimento social e pela humanização do mundo e dos sujeitos em condições de existência precária e de vulnerabilidade socioeconômica. Suas formulações, construídas com base no aparato teórico da filosofia humanista cristã, foram importantes desde então, marcando não apenas a pedagogia brasileira, latino-americana e mundial, mas também a própria história da esquerda latino-americana, sobretudo por sua vinculação com a democracia cristã e com os teólogos católicos da Libertação a partir da década de 1970 (Löwy, 2000, p. 136-140).

\section{CONSIDERAÇÕES FINAIS}

Como se pode verificar, os militantes católicos do pós-1945, assim como Paulo Freire, tinham os pés bem assentados na realidade e na contradição dela e reconheciam a dificuldade de operacionalizar ou pensar em soluções de aplicação fácil. Embora individualmente esses sujeitos militantes e engajados possam pertencer a mais de um campo social (Bourdieu, 2004), deve-se analisá-los, a exemplo de Freire, com base em sua especificidade de atuação em cada um dos campos, com o intuito de caracterizar sua condição de especialista e de interferência. E conhecendo esses grupos podem-se melhor reconhecer e caracterizar esses militantes com suas funções e atribuições nesse intricado jogo genealógico. Afinal, segundo Michel Foucault, a genealogia guarda estreita relação com a possibilidade de estabelecer o conhecimento válido acerca das coisas em um espaço e em um tempo determinados. A genealogia não é a construção de um desenvolvimento linear da história, mas pretende revelar os traços da influência e interferência das múltiplas relações de poder e de força sobre a vida das pessoas em um determinado passado que se apresenta sempre diverso, plural, polissêmico e contraditório (Foucault, 1979).

Considerando o que se apresentou até aqui, pode-se dizer que é possível avançar para traçar uma genealogia do catolicismo social brasileiro do pós1945 como um movimento organizado e atuante nos espaços públicos e institucionais. Havia, de fato, uma intencionalidade de "converter" e de formar um quadro de agentes católicos engajados e militantes, impedindo de se tornarem conservadores, de agir politicamente nos partidos políticos (PDC), nos governos estaduais e federal e nos sindicatos a partir de uma doutrina social católica, adaptando ao Brasil os estudos teóricos do desenvolvimento humano e 
integral francês. Chegava a hora de lançar-se numa cruzada por mais moradias e educação de base, organizar empresas comunitárias pelo princípio da cogestão, redefinir a ética econômica do dirigente empresarial e industrial, fomentar as experiências das Ligas Camponesas e aproximar-se dos espaços de atuação comunista seja para contrapô-la seja para eleger aquelas ideias ou ações consideradas adequadas e afins. Era a tentativa de consolidar um protagonismo social católico brasileiro por meio do desenvolvimento econômico integral e humanista e por uma educação libertadora.

\section{REFERÊNCIAS}

BETTO, Frei. Batismo de Sangue: guerrilha e morte de Carlos Marighella. Rio de Janeiro: Rocco, 2006.

BOSI, Alfredo. Economia e humanismo. Estudos Avançados [online]. v. 26, n. 75, p. 249-266, 2012.

BOURDIEU, Pierre. O campo científico. In: ORTIZ, Renato (org.). Pierre Bourdieu. São Paulo: Ática, 1983.

BOURDIEU, Pierre. Os usos sociais da ciência: por uma sociologia clínica do campo científico. São Paulo: Ed. Unesp, 2004.

BRESSER-PEREIRA, Luiz Carlos. As revoluções utópicas dos anos 60: a revolução estudantil e a revolução política na Igreja. São Paulo: Ed. 34, 2006.

COELHO, Germano. MCP - História do Movimento de Cultura Popular (1960-1964). Recife: Ed. do Autor, 2012.

FOUCAULT, Michel. Microfísica do poder. Rio de Janeiro: Graal, 1979.

FREIRE, Paulo. Educação como prática de liberdade. Rio de Janeiro: Paz e Terra, 1967. FREIRE, Paulo. Os cristãos e a libertação dos oprimidos. Lisboa: Base, 1978.

FREIRE, Paulo. Conscientização: teoria e prática da libertação. São Paulo: Moraes, 1980. GADOTTI, Moacir (org.). Paulo Freire: uma biobibliografia. São Paulo: Cortez, 1996. GÓMEZ DE SOUZA, Luiz Alberto. A utopia no meio de nós. Rio de Janeiro: Mauad, 2003.

LIMA, Alceu Amoroso. Sugestões de um Partido Político. A Ordem, Rio de Janeiro, p. 105, ago. 1945.

LÖWY, Michael. A guerra dos deuses: religião e política na América Latina. Petrópolis: Vozes, 2000.

MARITAIN, Jacques. Cristianismo e democracia. [1942]. Rio de Janeiro: Agir, 1945.

MARITAIN, Jacques. O homem e o Estado. [1950]. Rio de Janeiro: Agir, 1950.

MARITAIN, Jacques. Humanismo integral. [1936]. São Paulo: Dominus, 1965.

MOUNIER, Emmanuel. O personalismo. [1950]. São Paulo: Centauro, 2004.

NERUDA, Pablo. Confesso que vivi. São Paulo: Círculo do livro, 1980. 
PELLETIER, Denis. Economie et humanisme: de l'utopie communautaire au combat pour le Tiers-Monde, 1941-1966. Paris: Le Cerf, 1996.

POULAT, Émile. Eglise contre bourgeoisie. Tournai: Casterman, 1977.

SOUZA, Rogério Luiz de. A ética católica e o capitalismo de bem-estar social. Lisboa: Esfera do Caos: FCT/CLEPUL/Universidade de Lisboa, 2015.

SOUZA, Rogério Luiz de. Militância e engajamento católico diante dos processos de mudança político-social no Brasil (1945-1970). História - Debates e Tendências, Passo Fundo, RS, v. 9, n. 2, p. 288-298, 2009.

SUAUD, Charles. Prêtres et ouvriers: une double fidélité mise à l'épreuve - 1944-1969. Paris: Karthala, 2004.

Artigo recebido em 24 de setembro de 2018.

Aprovado em 15 de janeiro de 2019. 